\title{
A SHORT HISTORY OF GERMAN-MALAY(SI) \\ AN CULTURAL ENCOUNTERS IN THE LIGHT \\ OF GERMAN FOREIGN CULTURAL POLICY
}

\author{
Hans Volker Wolf
}

\begin{abstract}
While cultural contacts between Germany and Malaya in the 19th century happened mainly on the basis of personal or business relations, the dimension of cultural encounters between Germany and Malaysia took a different character in the 20th century. The Foreign Policy of the Weimar Republic, The Third Reich and the German Federal Republic institutionalized culture in various ways, which lead to the foundation of official cultural centers around the world. Today's Goethe Institute as the main cultural representative of the German Foreign Office has in the wake of such changes become a widely known partner for Malaysia in cultural and educational cooperation. It is the main objective of this paper to highlight these inter-and crosscultural relations - as exemplified in the work of the Goethe Institute - and to describe how they had gradually become an integral part of German Foreign Policies. Pointing towards the future, the author of the paper poses the question if a Malaysian 'P. Ramlee Institute' could not likewise represent the unique Malaysian intra-and cross-cultural style of cooperation on an international political stage.
\end{abstract}

Keywords: German-Malaysian cultural relations, German foreign cultural policy, Goethe Institute, National Cultural Centres

\section{INTRODUCTION}

The cultural dimension of foreign policy has been internationally acclaimed and utilized since the middle of the last century: Various countries institutionalised their intercultural ${ }^{1}$ work by establishing cultural centres - some of which have been active in Malaysia for many years. Next to the British Council (United Kingdom), the Alliance Française (France), Miguel Cervantes (Spain), Istituto Dante Alighieri 
(Italy) and the Japan Foundation it is also the German Goethe Institute that has achieved a widely approved reputation in Malaysia as one of the European partners in culture and education. German cultural events helped forge personal and institutional exchange between both countries and educational cooperation introduced hundreds of Malaysians to German universities and brought German academics into the tertiary education system of Malaysia - as is the case with the author of this article himself.

The underlying concept and linkage between political, economic and cultural cooperation in the context of foreign diplomatic relations has recently been discussed in this journal, on the "cultural diplomacy" of India and China by Palit. ${ }^{2}$ Since intercultural cooperation is also an integral part of German foreign policy and key to understanding the German-Malaysian relationship at large it is the objective of this research-based article to underline its principles in a chronological description, which goes hand in hand with an explanatory analysis of major German cultural activities in Malaysia. The extensional ${ }^{3}$ and exemplary side of defining the specifics of German intercultural cooperation is methodically meant here to outweigh intentional theory. This article therefore focuses on the institutional concept and practice of the German Cultural Centre, the largest representative of German cultural policy in Malaysia in order to demonstrate how German culture was officially presented to the general public in Malaysia from the middle of the 20th century into the first decade of the 21 st century $\left(1958 / 61-2006 / 13^{4}\right)$.

Lack of academic research in this phenomenon of noncommercial but government induced German cultural and educational work made it necessary to collect basic, prime and novel information in a descriptive fashion. The Goethe Institute (GI) archives in Kuala Lumpur and its Munich headquarters, and the Malaysian New Straits Times newspaper provided the supportive facts for this endeavour. The analytical approach was implicitly dealt with in the course of relevant exemplary developments, activities and events given. The recent history from the mid-20th and the early 21 st century has been extended into a chronological narrative of recorded beginnings. Early historical glimpses at prior German cultural contacts with Malaya during the 19th century are quoted and discussed in order to show the conceptual differences based on individual and personal interests 
of early encounters. In comparison to modern day planning such early contacts had organically grown out of a particular economic environment, whereas current German diplomatic objectives have been developed during different historical stages of politics and foreign policy.

\section{TRADITIONAL CULTURAL CONTACTS BETWEEN GERMANY AND MALAYA, 1850s-1920s}

Research on German foreign policy in the 19th and early 20th century reveals the inner: ${ }^{5}$

... dynamics of the German Empire. Between its foundation in 1871 through war and its downfall in 1918 at the end of war ... its turn from a predominantly continental policy to the new concept of imperialist 'Weltpolitik' in 1897-8 occupies a central position, because the decision for 'Weltpolitik' made world war almost inevitable.

It was, however, the very development of the international shipping trade and commercial exchange between Europe and the Pacific region in the second half of the 19th century which was at the core of German foreign policy that cleared the way and prepared first cultural contacts between German and Malayan individuals. Such contacts were intrinsically motivated and personally justified and they happened without much supportive intervention by the German government at the time. ${ }^{6}$ Public exposure and possible effects on the Malay public were limited to the network of Malay-German business partners and their associated German business communities, as Khoo Salma Nasution indicates in More than Merchants: A History of the German Speaking Community in Penang, 1800s - 1940s. ${ }^{7}$

One of the first Germans with distinct cultural interests who visited the Malayan Archipelago was Karl May, a popular German author of numerous adventure novels, many of which were translated into Bahasa Indonesia in the second half of the 20th century. ${ }^{8}$ Karl May came to Penang in 1899 and described his experiences fictionally in his novel Und Friede auf Erden! [And Peace on Earth!]. ${ }^{9}$ Only three years after this book had been published, the German reader was given an artistic visual insight into the social reality of the Straits Settlements 
and the Federated Malay States by German photographer Charles J. Kleingrothe who lived in Medan and published a picture-book with more than 130 photographs of Peninsular Malaya. ${ }^{10}$ Already from the 1860s onwards, professional German photographers had set up studios in the Straits Settlements and dominated the business until the First World War started. Very influential was J. M. Nauta, who first had a studio in Singapore in 1860 and then opened a shop in Penang that existed from the late 1870 s to the late 1880 s. He produced various photo volumes of Penang scenery and of native life. Some of his assistants were August Kaulfuss with his Penang postcards, Albert Schlumpf and the above-mentioned Charles J. Kleingrothe.

Before the First World War, the German-speaking community formed the second largest European trading community in the Straits Settlements after the British. Like other foreign nationals, the Germans tended to form clubs and associations with musical evenings, sports events and newspapers. The Deutsche Vereinigung [German Association] was formed in Penang in 1898.

At the beginning of the 20th Century (1911), one of Germany's most prominent novelists, Hermann Hesse - who was later in his life awarded the Nobel Prize for Literature (1946) - was on his way through Penang and the Malay Peninsula ${ }^{11}$ with his Swiss friend and artist Hans Sturzenegger who produced some pencil drawings of local scenes. These early art pieces experienced a late revival when they were exhibited with the help of the Swiss Schaffhausen Museum ${ }^{12}$ at the Penang E\&O Hotel during the launch of Khoo's book in 2006 thanks to the Goethe Institute and the Swiss and German embassies. In the diary of his journey through Asia, Hermann Hesse as one of the few influential intermediaries between 'East and West' wrote the following words about Georgetown (Penang): "the city funnily elegant, some kind of pseudo renaissance of old state and private department stores, the Chinese houses simple, light, pretty."13

Looking closer at literature, it occurs that not all the Germans were just accidental tourists who had been attracted to economic German strongholds in Malaya but that they had also personal interests of academic nature in the Malayan literary heritage. By 1920, Hans Friedrich Overbeck (1882-1942), an exporter from Bremen and passionate student of Malay language and cultural traditions who had 
been living in Singapore since 1902, finished his German translations of some of the most important works of Malay classical literature which were subsequently published in Germany. ${ }^{14}$

Whereas many of these economically motivated cultural encounters between Germans and Malayans happened in the 19th and early 20th century it was the First World War that stopped cultural relations abruptly and thoroughly. German companies were shut down, German citizens evacuated, detained and interned and it took years into the 1920s before some old threads could be picked up again: "it is likely that the German firms in the Strait Settlements, which survived the financial ruin of the war (...) formed new partnerships or reestablished themselves." 15

After the First World War (1914-1918) the German KaiserReich changed politically into the Weimar Republic (1919-1933). For once, Germany's foreign policy was no longer focused on aggressive aspirations to become one of the leading powers in the world but to build up trust in German reliability and good will instead of colonial and imperial exposure of power. While such thoughts had already been expressed by people like Karl Lamprecht in $1912^{16}$ they found their nourishing ground in German arguments mainly to explain and legitimize the loss of the First World War: lack of knowledge about the enemies was as much the result of soul-searching as the failed marketing of Germany as a civilized and cultured nation. German culture was seen as the common denominator of a young nations' identity and was meant to become its best branding item in the future.

While philological subjects in German schools and universities integrated foreign culture and civilization into their curricula, ${ }^{17}$ German schools were founded overseas and the support for cultural activities of German societies and for emigrant emissaries to foreign countries was politically enforced. In 1925, the Deutsche Akademie (German Academy) was founded which dedicated its work to the teaching of the German language and culture at home and abroad. The German Academy became later the umbrella organization for the Goethe Institute which took care of the training of international foreign teachers and lecturers of German in 1932, at the same time as the British Institute was set up in Munich. ${ }^{18}$ Another German educational mediator, the German Academic Exchange Service (Deutscher 
Akademischer Austauschdienst or DAAD) - that has been active in Malaysia for decades and is the official German mediating agent for studies in German universities - originates from those years (1928/9) as well.

Realizing that in addition to the value of languages as instruments of international understanding it was even more important to penetrate deeply into cultural understanding of other nations ${ }^{19}$, the German Foreign Office created its first cultural department in the year of 1920; cultural affairs had previously been part of their legal department. It was certainly no coincidence that the above-mentioned German academic interests in Malaya started during these years of the Weimar Republic. Among the German scholars who translated and published Malay fairy tales, folk songs, pantuns and dictionaries were ethnologist Paul Hambruch and linguists like Hans Nevermann, Hans Kahler or Irene Hilgers-Hesse, who all widely spread the knowledge of Malay culture and traditions in Germany. ${ }^{20}$

\section{GERMAN FOREIGN POLICY IN THE THIRD REICH} (1933-1945)

The National-Socialist government continued the foreign cultural policies of the Weimar Republic without any conceptual changes. The cultural department within the foreign office turned into the so-called 'culture and politics department' in 1936. Educational and cultural activities were expanded over the years and the first cultural agreements (with Italy and Japan) were signed in 1938. The German Academy diplomatically managed to keep cultural propaganda at bay and to preserve the relative independence that they explicitly claimed as the essential core of their concept. It was a matter of great importance to them that they did not become part of the newly set up Propaganda Ministry of Joseph Goebbels but could still work under the protection of the foreign office. ${ }^{21}$

Joachim von Ribbentrop the new Foreign Minister from 1938 to 1943 - a former wine merchant - maintained that his cultural policy abroad was a perfect example of success because it had brilliantly proven that culture can help gain influence over foreign powers. ${ }^{22} \mathrm{He}$ managed to keep the German Academy under the wings of the Foreign Office despite continuous forays by the Propaganda Ministry that it 
should be managed by them. After the beginning of the Second World War the foreign cultural policy was strongly intensified. Supportive arguments still referred to lessons learnt in the First World War: Germany did not want to be perceived as an aggressively barbaric and uncultured power. By 1941, the German Academy had sent 120 language lecturers abroad and counted 17,000-language students worldwide, a number that was to increase by 1942 to 198 lecturers and over 40,000 students. ${ }^{23}$ Ludwig Siebert reported in the Völkischer Beobachter [Ethnic Observer], the national-socialist daily on 19 October 1940 under the heading of "German a World Language", that "by intellectual prowess and life style the German people will attract the attention of the world as much as through armed victory."

When the Propaganda Ministry finally took over and integrated the German Academy as a corporate body the question arose how culture and education could still remain independent. Even the British Council - which was set up in 1935 by the British Government claimed that it was simply impossible in times of war to distinguish between culture and politics. ${ }^{24}$ And yet, cultural policy was still appreciated and widely valued as an expression of unlimited trust in victory, even in times of total war. ${ }^{25}$ If such German-based view may easily appear biased, it comes as a surprise that people like Graf von Posadowsky, the German Academy's lecturer in Spanish Cartagena - who had overstayed his posting beyond the capitulation of the Third Reich and the closure of his academy - was still employed by the Spanish side as their German lecturer until 1953 when he finally became the director of the newly reopened Goethe Institute in Athens, Greece. ${ }^{26}$

As to the German presence in Malaya during the Second World War, it was mainly the submarines that shaped the German reputation. In close cooperation with their Japanese allies the German navy established a German U-base on the island of Penang in 1943. ${ }^{27}$ The German community of Penang, however, had hardly had enough time to reestablish and to regroup into a new life style after the First World War when they were destined to lose everything once again. The third historical group of Germans who came to establish a new community in Penang after the Second World War had then to start from scratch. 


\section{CULTURE AS THE THIRD PILLAR OF FOREIGN POLICY IN THE FEDERAL REPUBLIC OF GERMANY (1960s-)}

As late as 1986, when the German writer Ernst Jünger spent a couple of weeks in Malaysia to see Halley's comet ${ }^{28}$ and was assisted by the German Embassy in Kuala Lumpur, political times had effectively integrated culture into their vision again. ${ }^{29}$ Some examples from the 1980s may illustrate this particularly well because it was only in the decade of the 1980s when such revised cultural policy from the 1960s had indeed shown its first practical effects on German-Malaysian cultural ties.

It also happened in the year of 1986, that Professor Muhammad Haji Salleh, one of the Malaysian National Poet Laureates, was awarded a scholarship by the German Volkswagen Foundation - with the help of the German Embassy - to finance his linguistic and literary research on traditional classical Malay texts in European libraries. ${ }^{30}$ In 1987, exactly twenty-two years after the first translation of the Brothers' Grimm fairy tales into Bahasa Malaysia [Grimm Bersandara - Cherita-Cherita Dongeng Grimm] had been published by Tuan Haji Mohamad Yassim in sponsorship through the Association of German Publishers and Booksellers, yet another and much more comprehensive selection of the Grimm's fairy tales was published in Bahasa Malaysia, translated by Professor Datuk Asmah Haji Omar of the University of Malaya (currently Professor Emeritus at the Faculty of Languages and Linguistics) with support of the German State of Baden-Württemberg. ${ }^{31}$ It was in February 1988 when: ${ }^{32}$

The German Embassy, with the assistance of the Goethe Institute has agreed to finance Dewan Bahasa dan Pustaka to translate some popular German literary works into Bahasa Malaysia. In addition, the embassy will also provide training and exposure to local translators to absorb German culture and lifestyle in the course of the project.

Back in the late 1960s many public discussions in Germany had focused on foreign cultural policy when a Parliamentary Enquete Commission was established to argue the point of culture and politics from an expert point of view. ${ }^{33}$ It was finally Foreign Minister (1966- 
69) Willy Brandt's notion that culture should be the third pillar of foreign policy next to the pillars of security and economic policies. The German Foreign Office's budget has consequently been equally divided between these three new foreign policy family members ever since.

Forty years later in 2011 this official terminology and nomenclature changed from German Foreign Cultural Policy to German Foreign Culture and Education Policy with an overall budget of $€ 1.5$ billion for all foreign political activities in culture and education. The general programmatic guidelines of the German Foreign Office as based on Brandt's vision of the late 1960s clarified the objective to "finding global partners, sharing values, explaining interests. ${ }^{34}$

Cultural and educational programmes are tailored to the needs and interests of people in partner countries; they not only create a broad basis for stable international relations but also build trust in Germany around the world. As a result of such programmes, German civil society, business and political actors readily find a host of important and reliable partners to work with.

In explicit detail, German cultural relations and education policy objectives are to:

- $\quad$ present Germany as a country with a lively, multifaceted and internationally renowned cultural scene;

- $\quad$ strengthen Germany as an education, science and research location by awarding scholarships, for example, to students and outstanding young researchers from all parts of the world;

- $\quad$ promote interest in the German language internationally;

- $\quad$ create a stable foundation for international relations by fostering dialogue and encounter.

The German Foreign Culture and Education Policy is still being financed by the German Federal government and solidly based on the foreign mediators for culture and education which are mainly the GI, the Alexander-von-Humboldt-Foundation, the German Archeological 
Institute, the Institute for Foreign Cultural Relations, the German Academic Exchange Service and the German International School system. Different from cultural commitments in the foreign policy of other states it is essential that all these German cultural and educational mediators are given independence from government intrusion.

\section{The German Cultural Centre, The Goethe Institute in Malaysia (1958/1961-2006/2013)}

The GI is the largest cultural mediator in this German Foreign Culture and Education Policy. Within the political objectives it is the GI's mission to present modern Germany by teaching the German language (to approximately 15 mil learners in 150 GIs world-wide) and by promoting cultural cooperation that allows for individual and specific decisions in local (e.g. in this case: Malaysian), regional (e.g. Southeast Asia Australia, New Zealand) and central (Head Office Munich) discourse with partners and interested parties: ${ }^{35}$

We draw our information from the many sections of our cosmopolitan society and culture, and combine the experience and ideas of our partners with our crosscultural expertise. We work on the principle of dialogue and partnership, and we offer our support to all those who are actively involved with Germany and its language and culture. We are an autonomous body and politically independent. We embrace the politico-cultural challenges of globalization. We achieve this through communication and by developing innovative concepts for a more humane world where cultural diversity is welcome as an enrichment of our society. Our partners are public and private cultural institutions, the federal states, local authorities and the world of commerce.

Since the general political guidelines formulated by the German Foreign Office are integrated into a wider frame of national cooperation with the other, often-local representatives of German policy, ${ }^{36}$ it is essential that the GI carefully coordinate its activities with all national and European mediators. ${ }^{37}$ Many of the German cultural and educational activities in Malaysia were covered in the Malaysian 
media from the 1960s onwards and all of them were organized and supported by the GI. The GI had been officially opened in Malaysia in 1961 - three years after the German Embassy had settled into Kuala Lumpur and the Goethe Institute had been first established (1958) - and started its bi-lateral diplomatic relations with the Malaysian Foreign Office in Kuala Lumpur and Bonn. The first press notice about the GI (1961) was provided on Dr. Peter Kreplin, its first managing director. ${ }^{38}$ Internationally, the GI is operating with 150 institutes worldwide and follows its contractual objectives and tasks as a German non-profit organization..$^{39}$ The German Foreign Office is one of the GI's board members and its major financial supporter. The constitutional objective and motto of the GI is:40

to promote the study of German abroad, to encourage international cultural exchange and to foster knowledge about Germany by providing information on its culture, society and politics.

As mentioned before, the GI began its work in Kuala Lumpur with an office in Lorong Thambi Abdullah in Brickfields in 1958:41

248 Malaysian students were enrolled in German classes. German classes where taught at the UM engineering faculty, where German had been made a compulsory subject for fourth and final year students, and German classes had also started in the Arts Faculty with 57 students enrolled. In addition German classes were held for Form Six students of the Methodist Boys' School.

In those early years German was not the only language taught at the GI and the Malaysian Minister of Education praised the GI for starting national (i.e. Bahasa Malaysia) language classes to the benefit of its own German community members. In 1963, the Goethe Institute moved into No. 1, Jalan Langgak Golf. ${ }^{42}$ By then, already ten German music concerts had been held and the first Malaysian woman had just qualified - with the help of the GI - as the very first Malaysian teacher of German. ${ }^{43}$ Just like all the other official cultural centers in Malaysia (e.g. British Council, Alliance Française, Japan Foundation) the GI offered language classes to Malaysians, helped train Malaysians to become teachers of German, informed Malaysians about Germany, 
promoted German Culture in Malaysia and assisted Malaysian Culture with their representation in Germany.

Since concepts are realized by human beings it was the GI directors $^{44}$ themselves who interpreted the general values and objectives of official German cultural and educational policy in their own ways according to their own personal experiences. The Malaysian media often gave them voice to their differentiated views and thereby showed clearly how a personal - and often heart-felt - presentation of German - predominantly 'classical' - culture had turned into a modern, subject-related and focused democratic expression of equal German and Malaysian partners. Personal 'good will' slowly turned into a systematic transfer of knowledge and know-how without seeming to lose its original human touch.

The personal charm of early beginnings was represented by Herr Etienne Cabos (1963-1965):45

The German Cultural Institute of Kuala Lumpur is a house of open doors and of open hearts, a house of alert intellectual work and of the cheerful will to further men of Malaysia and men of Germany to the experience of their common values.

[There are the language classes and] the long row of good concerts ... have found their well-deserved places in the cultural life of the capital and in the remembrance of many music-loving hearts in Kuala Lumpur, in Singapore, at Penang and in other towns of Malaysia. Soloists, chambermusic groups, orchestras as highly qualified interpreters of European composers from the Middle Ages to our times what a blessed task!

But the highest aim and the best result of all the endeavors of the German Cultural Institute, hardly sizable, hardly measurable and yet and just therefore most weighty: The mutual knowledge, with somebody or other, at some time or other, of how much we need one another, how much we can help one another, how much we have in common with one another beyond all words, and how much we have 
to and are to trust one another. That is the task of all work done in the Cultural Institute: to find and to justify trust.

Herr Sallmann, the GI director from 1984-1990 who had personally founded the 'Suria String Quartet', in which he played under the name of Anh Cua, exemplifies the complete scope of his working objectives two decades later in great detail:46

The Goethe Institute has sponsored concerts by visiting musicians like the Jazz Trio Blue Box, Concerto Köln, Bavaria State Youth Orchestra, Tübingen Chamber Soloists, and the local Baroque Players and Choristers.... There have also been shows by Freiburg Dance Theatre and mime artiste Milan Sladek, a talk on 150 Years of Photography, and a seminar on Short Films from Germany, among many other things. On the art side, the institute has mounted countless exhibitions, the recent ones being the Bauhaus show and an exhibition of original etchings, lithographs and chalks by German Impressionists.

His successor, Dr. Matthias Rick (1990-1995), started his cultural work with a new twist and vision: ${ }^{47}$

I will continue the work of my predecessor. Though I can't play any instrument or give personal support, I can help by organizing something, he says. I'm not interested in having a big concert, I'd rather have 10 interested people in a workshop than 200 people who would enjoy a concert but forget about it afterwards. I will rather be concentrating on contemporary music. He says Bach and Beethoven were reviled during their time, as is modern music now, which is said to be devoid of melody. Culture often means something revolutionary, he says.

And five years later - as he was looking back - he said:48

In between intellectual pursuits like lectures and seminars on world economy, skilled occupations, vocational training, the effects of industry on the environment, working with the disabled, democracy and a seminar 
on the role and influence of religion in society with the prime Minister, Datuk Seri Dr. Mahathir Mohamad, as a participant - there were also the puppet theatres, jazz bands, classical ensembles and art exhibitions which fulfilled the aesthetic senses.

Yet another interpretation of the 'Goethe' objective was illustrated by Gerhard Engelking, who was the director in the GI Kuala Lumpur from 1995 to 2002; he completely identified himself with his work and even used his private home in Ampang as a - weekendopen only - art gallery under the name of 'Space 2324' for alternating exhibitions by German and Malaysian artists. He even went global and showed Indonesian, Japanese, Zairean, or Haitian art - which was not a genuine part of his German mission. But, just like his predecessors, he focused on presenting fine arts and music, favorably jazz and German youth orchestras to Malaysian audiences.

\section{Statistics on German-Malaysian Cross-Cultural Contacts (1962-2005)}

The individual interpretation of local GI representatives is one way of differentiating the conceptual objectives but the scope and content of cultural and educational statistics illustrate these programmatic statements more objectively and with practical examples: ${ }^{49}$

\section{German Language Courses at the Goethe Institute Kuala Lumpur}

(1962 - 2005):

Number of courses: 955

Number of examinations: 865

Number of units taught: 125.000

Number of students: 12.000

\section{Teacher Training Courses (Secondary and Tertiary, 1993 - 2005):}

Seminars: 100

Participants: 1.500

Number of Secondary Teachers: 25

Number of Secondary Students with German: 1.500 
Number of Tertiary Teachers: 35

Number of Tertiary Students with German: 1.000

\section{Library and Information Centre (1965 - 1993):}

Books and media borrowed: 88.000

Visitors, readers and members: 12.500

\section{Cultural activities (1965 - 2005):}

Total of all activities: 2.100

Total of participants and visitors: 840.000

Films shown: 900

Projects with social issues and Literature: 471

\section{Music performances: 232}

\section{Exhibitions: 292}

Theatre and dance activities: 102

Media projects: 87

NSTP articles on the Goethe Institute in English and in Bahasa Malaysia

(1961 - 2005): 582

Language Courses: 39

Teacher Training and Liaison work: 40

Literature: 26

Film events: 46

Social issues: 82

\section{Music: 137}

\section{Exhibitions: 182}

Dance and Theatre: 30

\section{German-Malaysian Cooperation in the Visual Arts}

The statistics show that of all cultural areas it was the art exhibitions that topped the number of activities in most years with an approximate average of 7 exhibitions each year since 1962. Malaysia - like most other South East Asian countries - has a strong visual culture and 
cherishes artists of world stature. Many of them were trained and educated overseas and supported with scholarships ${ }^{50}$ like Latiff Mohidin who studied in Berlin with a scholarship from the German Academic Exchange Service (DAAD) from 1962-1964. ${ }^{51}$

Outspoken director, Hans Sallmann comments on the Malaysian arts' scene in the following way: ${ }^{52}$

The Goethe Institute plans according to the things most asked for. There is a strong interest in art, besides an existing infrastructure of museums and galleries. Malaysian art has a high standard and some artists are absolutely excellent.

German art that was shown in Malaysia offered insights into the work of internationally acclaimed German artists (Barlach, Richter, Grieshaber, Baselitz, Polke) and allowed Malaysian artists an intellectual interchange. Exhibitions of internationally known and established artistic movements (Dada, Surrealism, Constructivism, Bauhaus), genres (lithography, woodcuts, photography, cartoons, animation, public art) and themes (environmental art, architecture and art, city planning) caused more and more didactic demand.

From the early sixties until the end of the 1980s it was mainly the National Library, the University Malaya and the Dewan Bahasa dan Pustaka that actively cooperated as partners in cultural events; it was them who opened their galleries to GI exhibitions. From the 1990s onwards, the Malaysian Institute of Arts (MIA), the National Art Gallery of Malaysia (NAGM), and the Petronas Gallery became the main outlets for German exhibitions.

Over the decades cross-cultural exchange with Malaysia became the two-way traffic it was politically meant to be - and Malaysia's best known living artist, Latiff Mohidin himself is a good example for this policy: the DAAD supported Latiff Mohidin's studies in Berlin, Latiff himself wrote Malay poems in Berlin which were translated and published later by him and his German confrere Askandar Unglehrt in Malaysia with the help of the GI and Horlemann Publishers (Bonn) in 2006. In 1987 Latiff translated the Georg Büchner play Woyzeck into Bahasa Malaysia together with the DAAD-Lecturer Volkmar Sturm for Dewan Bahasa dan Pustaka (the Malaysian Academy for the Malay 
language) in Kuala Lumpur. Finally, the GI assisted him in 2013 with the launch of his translation of Goethe's Faust I as well as with the exhibition of his Faust I illustrations through the publisher ITBM, the Malaysian Institute for Translations and Publications that was held in cooperation with the Bank Negara Galleries in Kuala Lumpur. ${ }^{53}$

In a similar way, Hans Sallmann had taken 70 pieces of Malaysian Contemporary Art to Germany in 1990, and quite a few artists and curators had been offered scholarships for short term studies, residencies or excursion stints and stays in Germany. In a fresh attempt by the National Art Gallery and the GI to promote Malaysian artists overseas it was Ilse Noor, a German-Malaysian artist who was taken to Germany for an exhibition by her 'NN Gallery' curators and the Ministry of Culture, Art and Heritage. ${ }^{54}$

The personal networking of Malaysian artists in South East Asia during the last decade has been very successful - with Adeline Ooi moving from Malaysian art management at 'Valentine Willie's Art Gallery' in Bangsar Baru to being the new Director of Art Basel Hongkong in $2015^{55}$ and they were assisted in their networking with regional GI and IfA (Institute for Foreign Relations) projects like 'ArtconneXions' (2006) which earned Malaysian artists like Yee Y-Lann much appreciation in Germany and in the South East Asian region.

\section{German-Malaysian Cooperation In Music Culture}

The second most popular genre of cultural activities in the 40 years of Goethe's existence in Malaysia was music. 232 musical performances make up an average of five music events each year. Music was received by the media as the major source of intercultural understanding. ${ }^{56}$ And yet, there are different conceptual evaluations of the presentation of music in cultural cooperation: While music has been used and enjoyed as a cultural icon which could represent the classical image of Germany as a nation of musicians, artists and philosophers, it was the GI director Matthias Rick who had the confrontational view in this matter: ${ }^{57}$

I'm not interested in having a big concert. I'd rather have 10 interested people in a workshop than 200 people who would enjoy a concert but forget about it afterwards. 
Rick combined the question of short and long-term effects with the question of visibility, sustainability and actuality. Since German classical music has an undeclared status of world heritage it is already taken care of by the Malaysian Philharmonic Orchestra (MPO), so, why not concentrate on contemporary music from Germany instead, as illustrated above: ${ }^{58}$

Bach and Beethoven were reviled during their time, as is modern music, which is said to be devoid of melody.

Culture often means something revolutionary.

The cutting edge of modern and contemporary culture slowly had moved into the focus of the GI's interest.

\section{German-Malaysian Cooperation in Language and Education}

It may suffice to conclude this list of comments on the GI's cultural activities by looking at the language teaching efforts:

The GI has trained 12.000 over students in the German language since 1961, or 260 on average each year.

Over the decades, the GI and the Ministry of Secondary Education in Malaysia had made various attempts to organize a structure for the training of German language teachers. Generations of public servants on both sides had failed to overcome the gap between the education systems, until two major incidents changed the picture: German universities, and practically all European universities - started to introduce the Anglo-American system of Bachelors' and Masters' degrees and offered study programs, especially in technical subjects that were taught in the English Language (the so called 'International Degree Courses') on a German language basis of only 240 hours. This change raised the interest of Malaysian students in the German Tertiary Education system considerably, especially since the German Tertiary Education is mainly based on state universities and as such charges their students no fees. The DAAD-statistics illustrate this point: in 2002 there were 200 Malaysian students studying in German universities. Since then the number has reached 1,000 students ${ }^{59}$ and more than 80 Memoranda of Understanding (MoU) between German and Malaysian Universities have been signed. 


\section{CONCLUSION}

Today, the interest in the German language is still high in Malaysia and the Malaysian interest in German university studies is growing even more. Since Malaysia has been exposed to German culture for over half a century, partnerships have been started, sustainable networks have been knit, more than 400 German companies have established their Asian basecamps in Malaysia, friendship and respect have facilitated relationships with European countries in a global style, and the popularity of the Malaysian Goethe Institute reflects this cooperation with the personal touch of their German representatives.

Statistical numbers and their reflection in the Malaysian media demonstrate that culture and education have become an essential part of German foreign policy that is far more successful with regards to intercultural German-Malaysian relations than the German Reich foreign policy of political aggression and territorial expansion. As soon as modern cultural and educational programmes were tailored to the needs and interests of people in partner-countries they not only created a broad basis for stable bilateral and international relations but they also built trust in Germany. As a result of such programmes, which foster dialogue and personal encounters on the basis of mutual intercultural and cross-cultural understanding German civil society, business and political actors readily find important and reliable partners in their host country to work with.

Italian Professor Corrado G. M. Letta, a former senior research fellow at the Asia-Europe Institute (AEI) of Universiti Malaya (20052007) agrees with this evaluation when he quotes the German Federal Government's Strategic Development Plan for enhancing Germany's presence in East Asia in his research commission for the Malaysian Foreign Office: ${ }^{60}$

Constant dialogue and an exchange of views on changes and developments will be necessary in order to extend cultural ties and pass them on to the next generation. Political and business circles have not yet fully recognised the potential of academic exchange. Cultural sympathies facilitate the process of getting to know each other and sharing our values. Our publicly funded cultural 
involvement in East Asia is mainly directed at multipliers and opinion leaders in the political, economic and cultural spheres.

Many Malaysian partners in the cultural scene reported to the $\mathrm{GI}^{61}$ that the Malaysian government has already been considering their own respective cultural institute for the representation of Malaysian culture and diversity in contrast to their former folkloristic and traditional cultural exposure through the Ministry of Tourism. If Johann Wolfgang von Goethe, the patron of the GI has helped to unite East and West through the work of a cultural institute so may P. Ramlee, the undisputed and commonly liked icon of Malaysian integration be able to help truly connect Malaysia with Asia and the world through Malaysia's own cultural institution. ${ }^{61}$

\section{NOTES}

1 The term 'intercultural' in the text of this article will be used according to Richard Brislin, Understanding Culture's Influence on Behavior, San Diego, CA: Harcourt Brace Jovanovich, 1993, p. 417, as reciprocal and mutual "contacts between members of cultures", here, the cultures of Germany and Malaysia.

2 Parama Sinha Palit, "Asia in the $21^{\text {st }}$ Century: India and China Engages Southeast Asia," Malaysian Journal of International Relations (MJIR), Vol. 1, Dec 2013, pp. 65-67.

3 "...the intentional narrative world is the prime target of semantic interpretation in a philosophical way, while the extensional world of examples represents the derived background," quoted from Alice Bell, Astrid Ensslin and Hans Rustad (eds.), Analyzing Digital Fiction. Routledge: London, 2013, p. 62 .

4 The Goethe Institute started to work in Kuala Lumpur in 1958, but it was officially opened only in 1961 and the articles in the book, "Guests for 50 year" cover the time from the very early days (1958) and also from the official start of the Goethe Institute's work (1961) until 2006 with some exemplary Goethe events reaching into 2013 which were not systematically covered.

5 Imanuel Geis, German Foreign Policy, 1871-1914, London: Routledge, 1976, p. IIX. 
6 Khoo Salma Nasution, More than Merchants. A History of the German Speaking Community in Penang, 1800s - 1940s, Penang: Areca Books, 2006. 7 John D. Legge, "Daftar Lengkap Karya Karl May," 12 April 2015, < http://www.anelinda-store.com/karlmay.php>

8 Khoo, More than Merchants, pp.13-15; Karl May, Und Friede auf Erden!, Bamberg: Karl-May-Verlag, 1958 (first published 1904); for a recent study on Karl May's Und Friede auf Erden! [And Peace on Earth], [Dan Damai di Bumi], see Kuswarini Prasuri, "A Shift of Ideology in the Translation of Karl May's Work 'Und Friede auf Erden!' into the Indonesian Language," International Journal of Comparative Literature \& Translation Studies, Vol. 3, No. 2, 2014.

9 All references to the following names and activities in the German community of Penang refer to Khoo, More Than Merchants, pp. 34-41.

10 Ibid., pp. 16-18.

11 Museum zu Allerheiligen, Klosterstrasse 16, Schaffhausen, <admin. allerheiligen@stsh.ch>

12 Herrmann Hesse, Aus Indien, [From India], Frankfurt: Suhrkamp, 1980 (first published in 1914), pp. 127-194.

13 For details on all the references to Malay(si)an-German literary relations, see Arndt Graf, "Takkan Melayu hilang di dunia: Malaysian-German literary exchange before and after 1957," Jurnal Dewan Bahasa, Vol. 5, No. 2, 2002, pp.18-20.

14 Khoo, More Than Merchants, p. 96.

15 Kurt Düwell, Deutschlands auswärtige Kulturpolitik 1918-1932. Grundlinien und Dokumente, Köln, 1976, p. 17.

16 For example see, Gunta Haenicke, Zur Geschichte der Anglistik an deutschsprachigen Universitäten 1850-1925, Augsburg, 1979, p. 90.

17 Walter Apelt, Die kulturkundliche Bewegung im Unterricht der neueren Sprachen in Deutschland in den Jahren 1886 bis 1945. Ein Irrweg deutscher Philologen [The culture-based movement in teaching modern languages in Germany during the years from 1886 to 1945 . A dead end road taken by German philologists], Berlin (GDR): Verlag Volk \& Wissen, 1967, p. 180.

18 Bericht über die Verhandlungen der 19. Tagung des Allgemeinen Deutschen Neuphilologen-Verbandes in Berlin vom 1. bis 4. Okt. 1924 [Reports and Minutes of Meetings by the General German Modern Language Association], Berlin, 1925, pp. 25-26.

19 The names of all authors and titles mentioned are easily accessible in the Internet and will therefore not be listed in these notes. 
20 Kurt Düwell, Deutschlands auswärtige Kulturpolitik 1918-1932, p. 86. See also, Michael Bloch, Ribbentrop: A Biography, London: Crown Publishers, 1992.

21 Jan-Pieter Barbian, "Kulturwerte im Zweikampf. Die Kulturabkommen des Dritten Reiches als Instrumente nationalsozialistischer Außenpolitik," [Cultural values in single combat. The cultural agreements of the Third Reich as instruments of National Socialist Foreign Policy] in Archiv für Kulturgeschichte, Vol. 74, 1992, pp. 414-459.

22 Eckard Michels, Von der Deutschen Akademie zum Goethe-Institut, Sprach- und auswärtige Kulturpolitik 1923-1960 [The German Academy turning into the Goethe Institute. Language and Foreign Policy 1923-1960], München: Oldenbourg, 2005, p. 155.

23 Frances Donaldson, The British Council. The First 50 Years, London: Jonathan Cape Ltd/ Random House, 1984, pp. 70-71.

24 Michels, Von der Deutschen Akademie zum Goethe-Institut, p. 185.

25 Ibid., p. 188.

26 Khoo, More Than Merchants, p. 106.

27 Ernst Jünger, Zwei Mal Halley. Tagebuch [On seeing Halley Twice. A Diary], Stuttgart: Klett, 1987.

28 See Scott Erb, German Foreign Policy: Navigating a New Era, London: Lynne Rienner Publishers, 2003, p. 219: "a German foreign policy norm, one that in the 1980s was a fundamental aspect of the German foreign policy culture."

29 Andreas Radtke (ed.), 50 Years Malaysian-German Relations. Portraits of Friendship - Then and Now, Kuala Lumpur: Embassy of the Federal Republic of Germany, 2008, p. 208.

30 Ibid.

31 Volker Wolf (ed.), Guests for 50 Years, Goethe in Malaysia-Malaysia in Goethe: The Story of a Cultural Dialogue, Kuala Lumpur: Soka Gakkai Malaysia, Goethe Institute Malaysia and German Alumni Association Kuala Lumpur, 2008, p. 10.

32 Willy Brandt's views and cultural interest as the Foreign Minister at the time are widely discussed in Hansgert Peisert, Auswärtige Kulturpolitik der Bundesrepublik Deutschland: Gutachten im Auftrag des Auswärtigen Amts [Foreign Cultural Policy of the Federal Republic of Germany: Advisory Opinion Commissioned by the Foreign Office], Bonn/Konstanz, 1971.

33 Bundesregierung, Jahresbericht, [German Federal Government, Annual Report], 12 April 2015, <http://www.bundesregierung.de/Webs/ 
Breg/DE/Themen/Jahresbericht_2011_2012/11_KulturMedienpolitik/6_ AuswaertigeKulturBildungspolitik/_node.html>

34 Wolf, 2008, p. 12.

35 As mentioned above with the extended list of the German Educational Exchange Service (PAD), German Commission for UNESCO (DUK), Max Weber Stiftung - Foundation for German Humanities Institutes Abroad (MWS), Federal Cultural Foundation (KSB), Haus der Kulturen der Welt (House of World Cultures, HKW) - and still leaving many others out.

36 Common European Culture (EUNIC, i.e. European National Institutes of Culture) activities were organized in Malaysia since 2013/2014 with the British Council, the Alliance Française (France), Miguel Cervantes (Spain) and Dante Alighieri (Italy).

37 Wolf, 2008, p. 7.

38 Its legal format is similar to a Sendirian Berhad organization in Malaysia.

39 “About us," Goethe Institute Kuala Lumpur, 20 April 2015, <http://www. goethe.de/ins/my/en/kua/uun.html>

40 Wolf, 2008, p. 10.

41 It moved into a building in Jalan Tun Razak, corner Jalan Langgak Golf which was bought by the German government from the Australian government and had been used as the Australian High Commissions' Officers Mess before: This oral information was passed on to the author from the German Ambassador, Dr. Günter Gruber on 12 April, 2014; this GI building had to be given up because the European Union had decided that it was not earthquake safe in 2008, which caused the GI to move into the Menara See Hoy Chan building nearby.

42 Today, there are almost 50 Malaysian German teachers in Malaysian Secondary Schools (Sekolah Menengah Sains and Premier and Day Schools) according to a telephone information with Ms. Hamidah Baba, the Coordinator of the German lecturer team at IPG KBA, the Pedagogical Seminar for Foreign Language Teachers in Kuala Lumpur on 22 September 2014.

43 Find the list of Goethe Institute Kuala Lumpur directors between 1958 (early establishment of GI/1961 (year of official opening) to 2012 in Wolf, 2008, p. 17.

44 Wolf, 2008, pp. 13-14.

45 Ibid., p. 14.

46 Ibid., p. 15.

47 Ibid., pp. 15-16. 
48 These statistics - in their original presentation - were collected by the author as director of the GI Kuala Lumpur in cooperation with the Archives of the Goethe Institute Head Office and the New Straits Archive and they are listed in Wolf, 2008, pp. 16-18.

49 For example the Australian Colombo Plan.

50 This information was given to the author by the artist and poet Latiff Mohidin himself on 22 July 2014.

51 Wolf, 2008, p. 14.

52 Johann Wolfgang von Goethe, Faust I, Beck 1989, first published in 1828/29, translated and illustrated by Latiff Mohidin from 2009 to 2012; the artistic book was finally published with three dozen drawings as Faust I, Terjemahan Latiff Mohidin in Kuala Lumpur by ITBM (Institut Terjemahan $\&$ Buku Malaysia, i.e. Institute for Translation and Publication Malaysia) in the year 2013.

53 Wolf, 2008, p. 19.

54 Alex Greenberg, "Adeline Ooi topped as director Asia for Art Basel," Art News (New York), 30 December 2014. See Adeline Ooi, "A Chronology of Events in Malaysian Art," in Wolf, Guests for 50 Years, Goethe in Malaysia - Malaysia in Goethe, pp.104-119.

55 See also, Volker Wolf, "German Music in Malaysia - A Diachronic History of Music Events and Genres (1965-1985-1995-2005) to Illustrate the Institutional Exposure and Reception of German Music to the Malaysian Public by Official German Sources," in Gisa Jähnichen (ed.), UPM Book Series on Music Research, No. 7, 2015, pp. 32-56.

56 Wolf, Guests for 50 Years, Goethe in Malaysia - Malaysia in Goethe, p. 15.

57 Ibid.

58 Guido Schnieders, "Studying in Germany," 12 April 2015, <http:// www.mgs.org.my/content/display/article/site:mgs_penang-param:study_ in_germany-link:1150>

59 Corrado G. M. Letta, Malaysia-Europe, Strategic Partnership for the Pacific Century, Vol. II: Bilateral Relations, Kuala Lumpur: Malaysian Ministry of Foreign Affairs, 2008, pp. 205-253.

60 Based on an interview with Mrs. Patsy $\mathrm{Ng}$, chief secretary and cultural assistant in the GI for 34 years (1979-2013) on 12 April 2012.

${ }_{61}$ Paraphrase of a personal statement made to the author by Mr. Mahadi, the current President of the German Alumni Association Malaysia (GAAM) on 14 July 2014. 